dollar and PD milk, while a negative effect of PD dollar on percent fat has been observed. However an extremely close negative correlation $(-0.59$ and -0.73$)$ has been found between the PD milk and PD percent fat for sires with high PD milk estimates both in the HolsteinFriesian and particularly in the Jersey breed. This is indicating a non-linear negative relationship between the two characters which is extremely close in the studied bull population and at the same time it is decreasing the level of correlation between $P D$ milk and $P D \mathrm{~kg}$ fat $/$ and probably between PD milk and kg protein as well $(r=0.16$ and $r=0.3 \mathrm{I})$ for the Holstein-Friesian and the Jersey breeds respectively. 60 per cent of the Holstein-Friesian sires caused a decline in PD conformation score and only I 4 per cent of the bulls has improved both percent fat and conformation score. PD $\mathrm{kg}$ fat is the only character which has shown a more or less positive relationship to the $\mathrm{PD}$ estimates of the four other characters.

\title{
COW EVALUATION WITH BLUP
}

\section{H. U. GRASER}

\section{Abt. für Tierzucht, Universität Hohenheim, Stuttgart}

Two different models for cow-indexing with BLUP were investigated. Model I, known as "repeatability model" used second and higher lactations as a repeat of the first one. It was assumed that all heritabilities were equal as were all correlations between any two lactations. In the second model, the "multiple trait model", each lactation was a different trait. With this model different heritabilities and correlations were applied. Both models were tested with datas of the Braunvieh population in Baden-Württemberg. The results were compared with each other. The overall correlation between the two breeding-values was 0.95 , ranging from 0.88 for the oldest group of cows to 0.98 for cows with only one lactation.

\author{
INTERACTION BETWEEN ENVIRONMENTAL INTENSITY \\ AND HOLSTEIN UPGRADING IN GERMAN FRIESIANS \\ C. JONGELING, S. MOKHTAR, H. J. LANGHOLZ \\ Institut f. Tievzucht und Haustievgenetik, 3400 Göttingen, Germany
}

About 60 ooo first lactation milk records of different Holstein Friesian crosses were analyzed in order to quantify interactions between genetic group and environmental intensity. It was found that the interaction " $\mathrm{HF}$-group $\times$ ecological region" is not important, whereas interactions "sires within genetic group $\times$ ecological zone" seem to be significant. On the other hand there are substantial interactions between HF-group and herd level so that utilization of the benefits of HF-crosses for milk production is obviously much greater at a high production level.

INFLUENCE OF DIFFERENT IACTATION DISEASES ON AVERAGE HERD MILK PRODUCTION

H. SOLBU

Dep. of Animal Genetics and Breeding, Agricullural University of Norway, As-NLH

In this paper, analyses, with the purpose of estimating the influence of different lactation diseases on average herd milk production, have been described.

The following results were obtained :

I. The frequency of cows in the herds treated for mastitis, ketosis, milk fever, fertility diseases, and all diseases accounted for 7 per cent of the total variance in average herd milk yield, when only these effects were included.

2. When including other "herd discribing" variables in the analyses, the "disease variables" accounted fot an increase in the described part of the total variance of only 0.7 per cent units. 